Editorial

\title{
Vulnerability to bioinvasions: Current status, risk assessment and management of ballast water through A regional approach - The Adriatic Sea
}

\section{A R T I C L E I N F O}

\section{Keywords:}

Maritime transport

Harmful aquatic organisms and pathogens

Ballast water management

Risk assessment

Port baseline surveys

Adriatic Sea

\begin{abstract}
A B S T R A C T
The United Nations recognised the transfer of invasive species across natural barriers as one of the greatest pressures to the world's oceans and seas. The BWM Convention sets the global standards on ballast water management (BWM) requirements, while recognising that regional and local specifics have to be considered for its effective implementation. In the Adriatic Sea cross-border activities were conducted to provide for essential information/data and tools to support a regionally coordinated implementation of the BWM Convention. This special issue contains 18 publications that include results and recommendations from studying the ballast water and management issues through sampling of ballast water on vessels, risk assessment for exemptions and BWM, biological and chemical port baseline surveys and monitoring conducted in ports along the Adriatic Sea coast, oceanographic conditions, ballast water sediment issues and their management in ports, and the implementation options of the BWM Convention through the Adriatic States' environmental law and institutions cooperation. Essential data and tools to support a regional approach in the implementation of the BWM Convention were provided, and are therefore available to the administrations of the Adriatic countries to enable protection of the Adriatic Sea environment, human health property and resources from negative impacts of ballast water being discharged in the area. Data, approaches and tools provided here may be helpful in any other region to support an effective BWM Convention implementation.
\end{abstract}

\section{Introduction}

The United Nations recognised the transfer of harmful organisms and pathogens (HAOP) across natural barriers as one of the greatest pressures to the world's oceans and seas, as those species, when being invasive, cause global environmental changes, and pose threat also to human health, property and resources (IMO, 1973; Carlton, 1985; Gollasch et al., 2002; Vila et al., 2010; Chan et al., 2019). Ballast water transferred by vessels was recognised as a prominent vector of such species, and it is regulated by the International Convention for the Control and Management of Ship's Ballast Water and Sediments, 2004 (BWM Convention) (IMO, 2004). The BWM Convention sets the global standards on ballast water management (BWM) requirements, while recognising that regional and local specifics have to be considered for its effective implementation (David and Gollasch, 2008; Bailey et al., 2011).

The BWM Convention aims to reduce the spread of HAOP among ports and areas, by establishing standards and procedures for the management and control of ships' ballast water and sediments. The BWM Convention defines HAOP as organisms which, if introduced into the sea including estuaries, or into fresh water courses, may create hazards to the environment, human health, property or resources, impair biological diversity or interfere with other legitimate uses of such areas (IMO, 2004). Accordingly, HAOP include potentially harmful non indigenous species (NIS) and cryptogenic species, harmful native species and pathogens (David et al., 2013; Gollasch et al., 2015).

In total $>1400$ aquatic non-indigenous species are known from
Europe (Gollasch, 2006; Vila et al., 2010; Katsanevakis et al., 2013; Reker et al., 2015), and > 986 NIS are recorded in the Mediterranean Sea, the highest number of all European Seas (Klaoudatos and Kapiris, 2014). Their economic impact is difficult to quantify (van den Bergh et al., 2002) and literature is scarce on this aspect. One study concluded that the estimated yearly economic loss due to the introduction of aquatic non-indigenous species is $\$ 14.2$ billion in the USA (Pimentel et al., 2005) and costs for repair, management and the mitigation of such species in Europe are $>1.2$ billion Euros annually (Shine et al., 2010).

The volume of ballast water discharged in the Adriatic Sea ports is estimated to be over 10 million tons per year and due to foreseen projects this could soon increase considerably. The presence of HAOP in ballast water discharged in the Adriatic ports was proven (David et al., 2007; Cabrini et al., 2019) and negative impacts have already been recorded in the Adriatic Sea (Zenetos et al., 2012; Katsanevakis et al., 2016). The Adriatic Sea is a unique and highly sensitive ecosystem. The economic development and social existence of the coastal states strongly depend on the clean and preserved Adriatic Sea (Kraus et al., 2016). However, the Adriatic Sea is also a seaway mainly used by international shipping to or from Europe as hinterland in addition to intense local shipping (Komadina and Zec, 1996; David and Gollasch, 2008). An increasing, serious concern is the introduction of HAOP by ships' ballast water (David et al., 2007).

Adriatic countries through regional cooperation (e.g., Interministerial Trilateral Commission for the Protection of the Adriatic Sea among Croatia, Italy and Slovenia) have recognised that the ballast 
water issue is very critical and complex. A key barrier recognised was the lack of data (e.g. the presence and invasiveness of HAOP in Adriatic ports, ballast water uptake and discharge activities, sediment disposal, chemical pollution with ballast water) and knowledge (e.g. port baselines and monitoring, ballast water sampling for compliance control, risk assessment, how to deal with non-compliant vessels, early warning system (Magaletti et al., 2018), effectiveness of BWM systems and measures) to enable Adriatic countries to implement the BWM Convention requirements through a common BWM approach. A strategic common cross-border approach was considered to be crucial also because of the shared, specific, vulnerable, economically important, semienclosed environment, in which HAOP as well as international shipping cannot be limited by political borders.

The Ballast Water Management System For Adriatic Sea Protection (BALMAS) strategic project identified and integrated the necessary activities to enable a long-term, environmentally efficient, and financially and maritime transport sustainable implementation of BWM measures in the Adriatic. The general BALMAS objective was to establish a common Adriatic cross-border system linking research institutions, experts and national responsible authorities to avoid the unwanted risks to the environment and humans from the transfer of HAOP, through the control and management of ships' ballast water and sediments. Further, BALMAS objectives included developments in related knowledge and technology at cross-border level for a long-term effective BWM in the Adriatic according to the BWM Convention, Europe wide developments and local specifics.

\section{Adriatic sea, maritime transport and ballast water issue}

The Adriatic Sea is the most continental basin of the Mediterranean Sea. It is located in the northernmost part of the Mediterranean Sea, between the Apennine and the Balkan peninsula. Its longitudinally elongated shape can be approximated to a rectangular basin $800 \mathrm{~km}$ long and $200 \mathrm{~km}$ wide, with the only connection with the Mediterranean Sea through the Otranto Strait (Lipizer et al., 2014). The Adriatic can be divided into three areas: the northern Adriatic - the largest shelf area in the Mediterranean, bordered by $100 \mathrm{~m}$ isobaths and characterized by the largest riverine contributions in the basin (Cozzi and Giani, 2011); the central Adriatic - characterized by Jabuka Pit or Middle Adriatic Pit, whose maximum depth is around $270 \mathrm{~m}$ (Marini et al., 2006; Grilli et al., 2013), in this area, Palagruža Sill (170 m deep) acts as a borderline area between the Jabuka Pits and the Southern Adriatic basin (Marini et al., 2016); and the southern Adriatic - which is connected to the Ionian Sea through the Otranto Sill (depth, $780 \mathrm{~m}$ ) and includes the South Adriatic Pit, the deepest area in the Adriatic, around $1200 \mathrm{~m}$ (Artegiani et al., 1997). The circulation of surface waters in the Adriatic Sea is predominantly cyclonic (counter-clockwise), i.e. along the eastcoast the waters move from south to north, while along the west coast from north to south. This circulation strongly influences the fluvial inputs and the transport of nutrient loads in the open sea. The main nutrient inputs to the Adriatic Sea come from surface runoff, underground water and urban discharges, and aeolian inputs (Marini et al., 2008). Temperature, salinity, nutrients, dissolved oxygen, and chlorophyll generally show a pronounced seasonal cycle and marked longitudinal gradients (Lipizer et al., 2014). From north to south, the Adriatic appears to be characterized by a progressive decline in nutrient concentrations in the surface layer and a decrease of seasonal cycle amplitude in the middle and southern areas (Zavatarelli et al., 1998).

Maritime traffic in the Adriatic Sea follows four main patterns (Fig. 1). The main Adriatic longitudinal route follows the main longitudinal axis of the Adriatic Sea. The total length is just over 400 Nautical Miles and links ports in the northern part of the Adriatic Sea with the Otranto passage. The second group of routes includes the crossing routes between the ports on the western and eastern Adriatic coasts. The third group of routes includes the routes connecting ports along the east and west coast of the Adriatic Sea, which in case of the western coast is domestic traffic only, while along the eastern Adriatic coast can be international. And the fourth group includes various irregular routes used by large cruise vessels, yachts, fishing vessels, as well as other small boats. According to available data on these ports, it is estimated that approximately 22,000 ships sail per year across the Adriatic Sea area (Zec et al., 2015; Zupančič et al., 2015).

The largest group is the general cargo vessel type, followed by bulk carriers, chemical and oil tankers (Fig. 2).

Ballast water discharge patterns in the Adriatic Sea were studied to obtain information about frequency of vessel calls, ballast water discharge profiles per vessel type and donor ports of ballast water. Twelve Adriatic ports (Koper, Trieste, Venice, Bari, Ancona, Rijeka, Pula, Split, Šibenik, Ploče, Bar, Durrës) were analysed based on the real maritime traffic data (David et al., 2016). In the period from 2012 to 2015 altogether 39,442 vessel calls were recorded of which an average of $22 \%$ vessels had been assessed to discharge ballast. These data include cargo vessels and other types of vessels (passenger, tug, reefer, etc.) since some ports take into account only cargo vessels and other ports all types of vessels. Information about ballast water discharge volumes and donor ports were obtained with ballast water reporting (BWR) and ballast water discharge assessments (BWDA). As most ports do not have BWR in place, BWDA has been used to assess discharge volumes. Based on BWR and BWDA, 8.4 million $\mathrm{m}^{3}$ of ballast water was estimated to have been discharged in the 12 selected ports from 2012 to 2015 (David et al., 2016). It should be noted that the real value is expected to be higher since some selected ports did not report for the entire time period considered here.

In terms of ballast water donor ports, the majority of ballast water is transferred inside the Adriatic Sea area, followed by the remaining Mediterranean Sea area, and $<10 \%$ is from ports outside the Mediterranean Sea (David et al., 2016). Even when donor ports are from the same ecoregions, studies have shown (e.g., David et al., 2007, see also this issue) that ports in the area already contain introduced species, hence these are then further spread as secondary transfer with ballast water.

\section{In this special issue}

The BALMAS project lasted from November 2013 to September 2016 and included 16 partners from six countries sharing the Adriatic Sea: Albania, Bosnia and Herzegovina, Croatia, Italy, Montenegro, and Slovenia. Most of the BALMAS project results are presented in the 18 publications of this special issue.

The opening paper of this special issue, Introductions and transfers of species by ballast water in the Adriatic Sea (Gollasch et al., 2019), provides background information on HAOP and the mechanisms (pathways) of their transport, shipping (ballast water and biofouling) being the dominant vector followed by aquaculture activities. In line with the aims of the BALMAS project, this paper highlights ballast water as the focus of an international convention to prevent future introductions of HAOP, and includes a review of management options and suggestions for future research needs.

The importance of BWM for the Adriatic is clearly pointed out by the results presented in paper Potential transfer of aquatic organisms via ballast water with a particular focus on harmful and non-indigenous species: A survey from Adriatic ports (Cabrini et al., 2019). Besides faecal contamination, investigated ballast water samples from several vessels calling in five Adriatic ports (Trieste, Venice, Ancona, Bari, and Koper), included harmful and potentially toxic phyto- and zooplankton species, with several phyto- and zooplankton NIS.

The risk assessment (RA) developed in the framework of the BWM Convention includes two fundamentally different approaches for its implementation, the selective and the blanket approach (David, 2007; David et al., 2015a, 2015b). The selective approach imposes appropriate BWM measures depending on different risk levels posed by the ballast water intended for discharge, whereas the blanket approach 


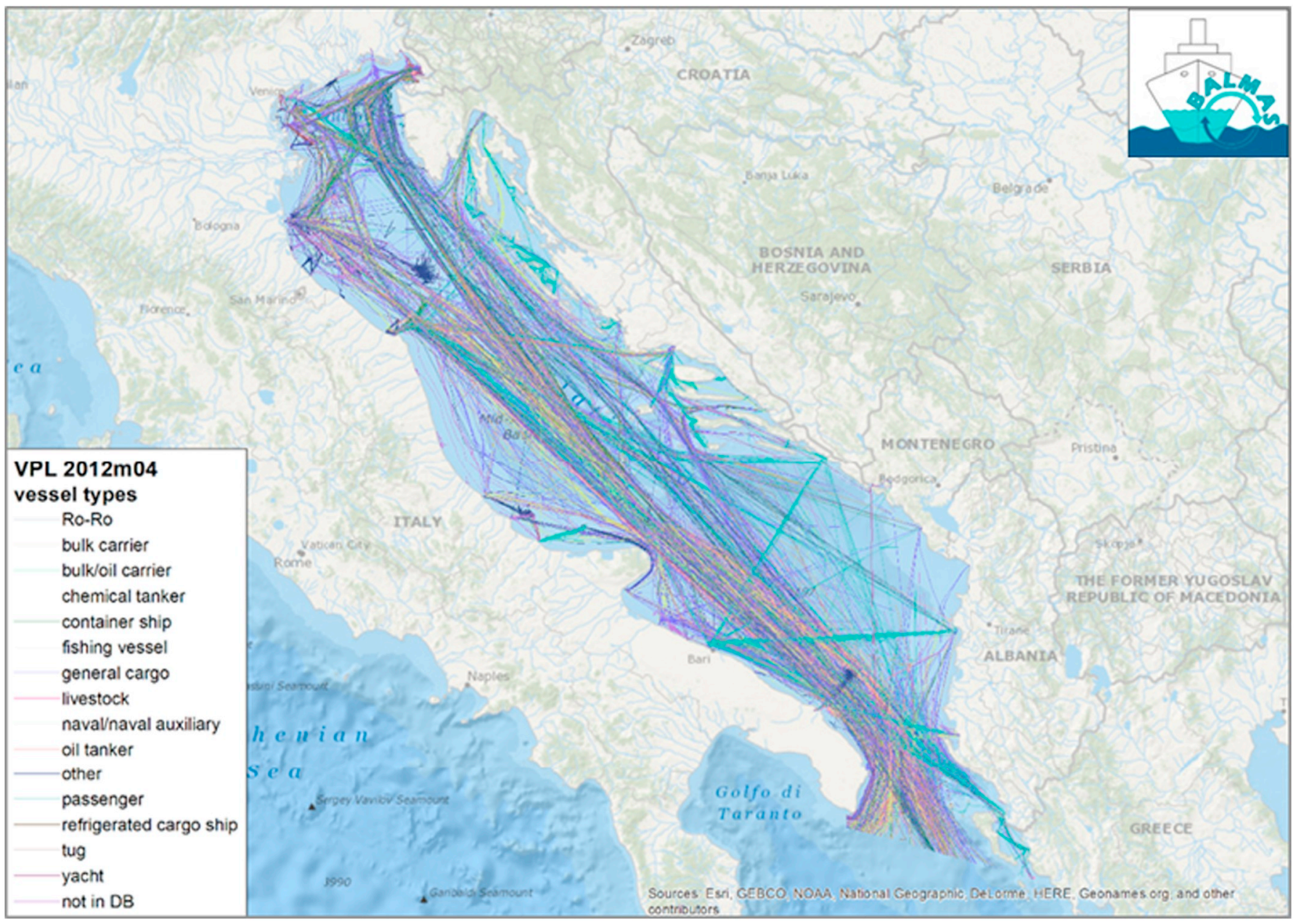

Fig. 1. Vessel path lines for April 2012 showing different vessel types (Zupančič et al., 2015).

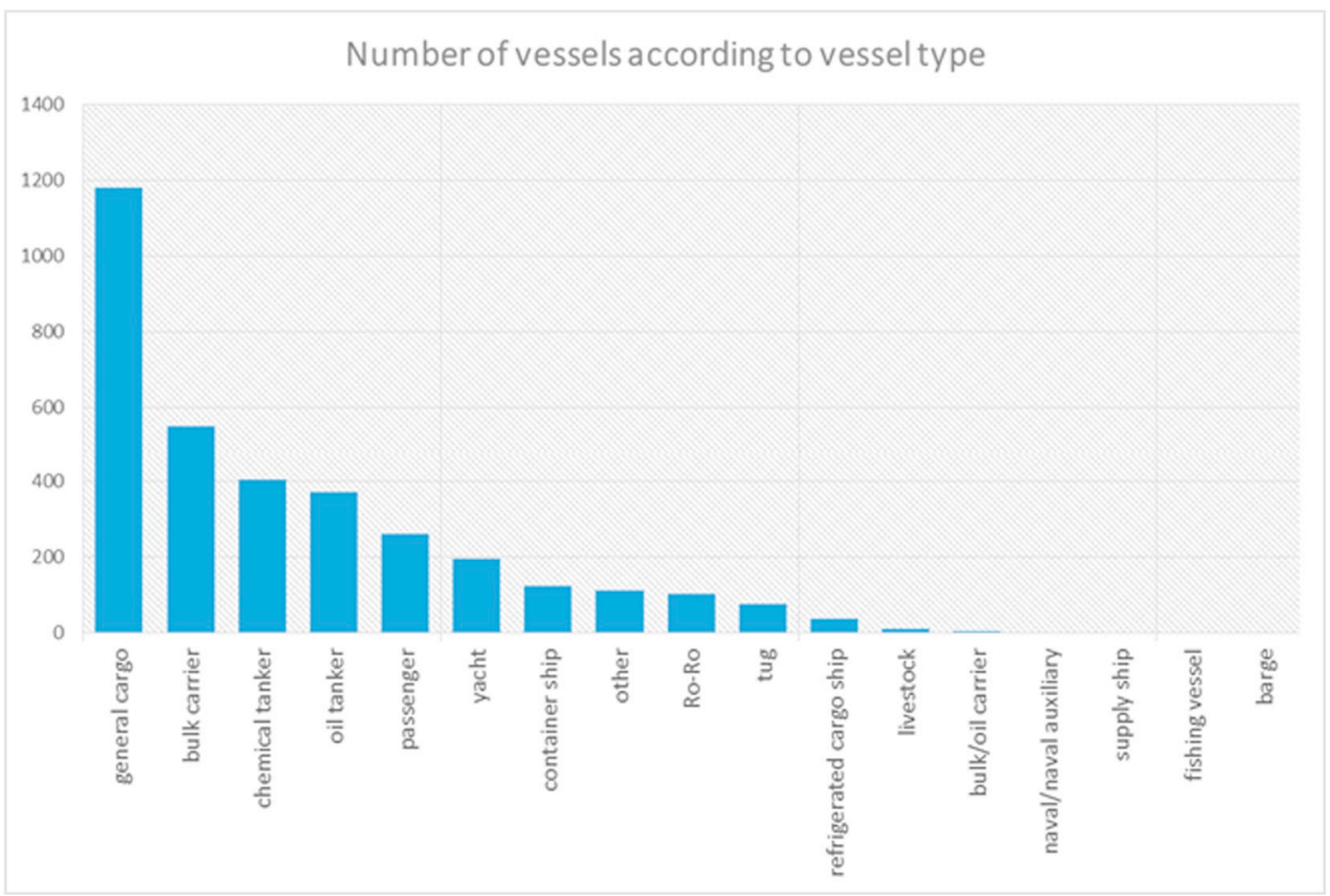

Fig. 2. Vessels by vessel type in the Adriatic Sea recorded in 2012 (Zupančič et al., 2015). 
applies to all ships intending to discharge ballast water in a port to conduct BWM, thus potentially generating an unnecessary burden to those vessels carrying low risk ballast water (David et al., 2015b). In the paper, Risk assessment for ballast water management — Learning from the Adriatic Sea case study (David and Gollasch), a new BWM RA model was developed to support the implementation of most efficient management measures. This model is applicable elsewhere to support and improve complex decision making in the implementation of management requirements according to the BWM Convention, which incorporates the three principles of risk assessment (IMO, 2007). This paper presents the improved version of the BWM RA model developed for European seas (David and Gollasch, 2014), which was now tested on four different cases using data from port environments, vessels traffic and ballast water discharges situation of the port of Koper. In addition, implementation options and issues were discussed, with recommendations for the BWM RA implementation in other areas.

The importance of targeted biological surveys in port environments as the most likely sites of arrival and settlement of new species is recognised in both legal and scientific publications dedicated to successful prevention, control and management of marine invasions (Hewitt and Martin, 1996; Hewitt and Martin, 2001; Awad et al., 2014). The above presented BWM RA should (at best) be based on reliable data (Lodge et al., 2006), such as results from PBS and monitoring of HAOP (David, 2007). Port biological baseline surveys (PBBS) are an essential tool to support effective management strategies for NIS as well as native HAOP (Bishop and Hutchings, 2011; Olenin et al., 2016). These surveys provide species inventories in and around ports, with a focus on NIS that may have been introduced by vessels, primarily via ballast waters (Awad et al., 2014). Depending on protocols guidelines, PBBS can: i) provide a valuable detection system for target species, facilitating species eradication before their proliferation and spread; ii) provide a baseline of native and NIS biodiversity to identify future new introductions; iii) help investigate invasion patterns in relation to abiotic and biotic factors; and iv) provide information on the effects of invasions (Bishop and Hutchings, 2011). One of the papers of this special issue, Strategy of port baseline surveys (PBS) in the Adriatic Sea (Kraus et al., 2019a), includes an overview of existing surveys protocols which provide valuable support to decision-making and to design effective NIS monitoring with conversed pros and cons. Furthermore, this paper offers guidelines for the selection of ports, survey areas, and sampling sites; the scope of parameters, i.e. sampling intensity, frequency and timing; as well as recommended and alternative methods of sampling, sample processing and analyses, which are initial stage in PBS planning.

PBS was conducted in 12 Adriatic ports, four in Italy (Bari, Ancona, Venice, Trieste), one in Slovenia (Koper), five in Croatia (Pula, Rijeka, Šibenik, Split, Ploče), and one each in Montenegro (Bar) and Albania (Durrës). This paper includes detailed explanation of the survey area and sampling sites in each port, while the details of the remainder of the guidelines, regarding parameters and sampling, are specified in separate papers of this special issue. Furthermore, it includes a description of the PBS protocol for the Adriatic, the protocol itself as supplementary material, and recommendations based on the Adriatic PBS experience.

In addition to the study of the biota, the Adriatic PBS protocol includes optional, abiotic parameters. Physical parameters were included to facilitate the understanding of processes in and around ports. In the paper, Oceanographic characteristics of the Adriatic Sea - Support to secondary HAOP spread through natural dispersal (Kraus et al., 2019b), estimations of HAOP spread pathways over the region, and, more specifically, from potential port of arrival to a wider area are presented. Namely, HAOP retention in port vs. HAOP flow out in open area followed by their potential inclusion in the general Adriatic circulation were estimated for each port, season, and for both surface and bottom layer.

Chemical parameters in the Adriatic PBS protocol were proposed to provide insight into impacts of chemicals used in oxidant treatment of ballast water and ballast water discharge. In the paper, Ballast water management system: Assessment of chemical quality status of several ports in Adriatic Sea, a baseline set of data concerning disinfection by-products (DBPs) was provided, indicating their release in relation to the treatment of ballast water, and butyltin (BT), particularly in the sediments, due to TBT past use or recent illegal application (Romanelli et al., 2019).

However, the species inventories presented in ten papers of this special issue represent the main result of the PBS performed in 12 Adriatic ports. Generally, these inventories are the first species inventories related to ports in this area. Although the main aim of the surveys was to investigate HAOP that may have been introduced in ports by vessels, primarily via ballast water, hull fouling as another vector was also considered (Gollasch et al., 2015; Gollasch and David, 2018). The latter was specifically addressed by the paper Port Baseline Biological Surveys and seaweed bioinvasions in port areas: What's the matter in the Adriatic Sea? (Petrocelli et al., 2019). The factors that may influence HAOP presence or absence, such as seasonality and strategies of sampling, were discussed. The paper also provides some specific recommendations regarding NIS surveys.

On the other hand, all numerous microscopic algae that can trigger harmful algal blooms (HAB) are considered HAOP, irrelevantly of their native or non-indigenous origin. Results of PBS aimed at microalgae were presented in the paper Phytoplankton diversity in Adriatic ports: Lessons from the port baseline survey for the management of harmful algal species (Mozetič et al., 2019). An inventory of the phytoplankton diversity in 12 Adriatic ports was compiled and suggestions regarding port surveillance were given. Apart from making the inventory of species in ports, a network analysis on seasonally aggregated data enabled the assembly of seasonal phytoplankton patterns and the identification of a similar seasonal outline of the ports. The paper also contains a catalogue of $\mathrm{HAB}$, as well as non-indigenous and cryptogenic species, along with their biological, ecological, and toxicogenic characteristics.

The first inventory of zooplankton taxa, which encompassed 10 Adriatic ports (Bari, Ancona, Venice, Trieste, Koper, Pula, Rijeka, Šibenik, Split, and Bar) is given in the paper Zooplankton in Adriatic port environments: Indigenous communities and non-indigenous species (Vidjak et al.). The paper includes an inventory of species, including observed NIS, with their spatial and seasonal distribution patterns. As the zooplankton communities in ports vary in relation to their geographical location and local environmental conditions, recommendations were given for sampling methodology and future surveillance.

PBS encompassed also benthic communities. In the paper, Non-indigenous macrozoobenthic species on hard substrata of selected harbours in the Adriatic Sea, the results of investigation performed in all 12 Adriatic ports were presented (Spagnolo et al., 2019). This paper also includes an account of each detected NIS regarding its origin, vector and pathway of spreading to the Adriatic, and specifically ports of observation. In the paper, Macrozoobenthos in the Adriatic Sea ports: soft bottom communities with an overview of non-indigenous species, the inventory obtained from five Adriatic ports (Bari, Ancona, Koper, Pula and Rijeka) was presented (Travizi et al., 2019). The paper includes an account of the origin, vector and pathway of spreading of the observed NIS.

Additionally, results of the investigation of one specific community in marine sediments were delivered in one separate paper, Meiofaunal communities in four Adriatic ports: Baseline data for risk assessment in ballast water management (Baldrighi et al., 2019). In this paper, investigated taxonomic composition of meiofaunal communities in four ports of the Adriatic (Ancona, Trieste, Koper, and Split), and their observed variations were discussed. Meiofauna was assessed for the main environmental pollutants in order to evaluate the effects of human activities on this community, and identify the most appropriate descriptor to assess the ecological quality of marine ecosystems. Namely, due to their small size, high abundance and species richness, fast generation, and direct benthic development, meiofaunal organisms can be used as biological indicators of anthropogenic impacts (Balsamo et al., 
2012; Zeppilli et al., 2015), whereas their community structure reflects organic matter and contaminant concentrations and oxygen levels (e.g. Marin et al., 2008; Moreno et al., 2008a, 2008b, 2009).

Another specific community investigated in marine sediment was presented in the paper Dinoflagellate resting cysts from surface sediments of the Adriatic Ports: distribution and potential spreading patterns (Di Poi et al., 2019). The ability of microalgae to preserve a viable status in coastal sediments as resting forms provides a reservoir of phytoplankton biodiversity albeit also of toxicity, as many dinoflagellates are identified as toxic and to cause harmful red-tide events (Matsuoka and Fukuyo, 2000). Investigation was conducted in nine Adriatic ports (Bari, Ancona, Venice, Trieste, Koper, Pula, Rijeka, Šibenik, and Split). Inventory of species including observed NIS and toxic taxa with possible spreading pathway scenarios by ballast water vs. natural spreading were hypothesised for all observed taxa. Determination of taxa was performed microscopically, differently to the approach taken in the paper Molecular methods for cost-efficient monitoring of HAB (harmful algal bloom) dinoflagellate resting cysts (Perini et al., 2019). An alternative approach to efficient and accurate quantification of several toxic taxa was developed and tested on sediment samples from four Adriatic ports (Bari, Ancona, Venice, and Trieste).

The use of the molecular method, quantitative (q)PCR, was applied and tested in the detection of pathogens as well. Namely, microbial requirements as the Ballast Water Performance Standard established by the D-2 Regulation of the BWM Convention include Escherichia coli and intestinal Enterococci as indicator of faecal contamination, i.e., as proxyindicators of the increased probability of pathogens' presence. Although worldwide coastal water quality is monitored for faecal pollution using the same faecal indicator bacteria (Field and Samadpour, 2007), ports are scarcely investigated. Faecal contamination was assessed in seawater and sediments in 12 ports of the Adriatic Sea, and results presented in the paper Status of faecal pollution in ports: A basin-wide investigation in the Adriatic Sea (Luna et al.). The culture-based methods currently used to quantify faecal indicator bacteria abundance were used in all ports, while this novel, rapid qPCR approach was tested as their alternative in one selected port.

The importance of integrating traditional monitoring tools with other complementary detection strategies has been stressed at both scientific and political levels (Hulme, 2006; Olenin et al., 2011, 2016), and the collaboration with local stakeholders, as one possibility, is particularly encouraged (Hewitt and Martin, 1996, 2001). Hardly any group of organisms is as suitable as marine megafauna, which by definition includes large animals $(>2 \mathrm{~cm}$ ), such as fish and decapods, which may be visible in photographs and could be relatively easily detected (Gooday et al., 2009). This participatory approach, often reported as 'Local Ecological Knowledge' (LEK), has recently emerged as an alternative information source on species' occurrence and distribution (Anadón et al., 2009). It is increasingly used in the Mediterranean Sea, and mostly with fish species (e.g., Azzurro et al., 2011). In the paper, Detecting the occurrence of indigenous and non-indigenous megafauna through fishermen knowledge: A complementary tool to coastal and port surveys, results of port surveys using traps and nets within 10 Adriatic ports (Bari, Ancona, Venice, Trieste, Koper, Pula, Rijeka, Šibenik, Split, and Bar) were compared with the information obtained from the local fishermen (Azzurro et al., 2019).

The BWM Convention includes provision of adequate reception facilities for sediment, removed from ballast tanks for cleaning or repair purposes, which enable safe sediment disposal - without any damage to environment, human health, property or resources. In the paper, Ballast water sediment management in ports, the possible effects of existing ballast tank sediment management routine in ports were estimated through an examination of respective legal frameworks from different states and the operational modes of selected Adriatic shipyards (Maglić et al., 2019). The bulk of sediment is introduced into the tank during ballasting operations, accumulation of various by-products during ballasting, corrosion and deterioration of the protective coating (Maglić et al., 2016). As during de-ballasting accumulated sediments only partially discharge with ballast water, further accumulation of all free living and suspended aquatic organisms that may occur in the water column and survive the ballasting process is facilitated (e.g., Carlton et al., 1995; Gollasch et al., 2015). One of the early studies of ballast water sediments in tanks reported that in "this mud" living polychaete worms and crustaceans, including and wide variety of amphipods, crabs and shrimps were found (Williams et al., 1988); a finding confirmed by numerous following studies (e.g. Casas-Monroy et al., 2011). The goal of this research was to determine if the States' administration and ports' management are aware of the risks that sediments pose to human health and the environment due to the possible presence of HAOP or high concentrations of heavy metals during sediment disposal from tanks.

The BWM Convention is one of several EU regulations addressing the issue of NIS, which are in the Convention encompassed in HAOP. In the paper, The implementation of the ballast water management convention in the Adriatic Sea through States' cooperation: The contribution of environmental law and institutions (Rak et al., 2019), based on legal and institutional information, and considering the regional maritime traffic and environmental specifics, essential steps in facilitating the implementation of BWM obligations were identified and discussed.

\section{Conclusions}

We believe that the publications of this special issue may provide useful and important insights into the mechanisms of transfer of organisms via vessels ballast waters, and their survival in ports. Information from PBBS and chemical surveys now offers an overview of the present situation, and establishes baseline information for water quality assessments, as well may support implementation of different BWM convention tools, e.g., RA for exemptions and BWM, Early Warning System, BWM Decision Support System. Activities conducted in BALMAS, which brought to these results, were essentially conducted as cross-border activities, thus facilitating continuing cooperation among the main institutions and laboratories in the Adriatic region. In conclusion, relevant missing data and tools to support a regional approach in the implementation of the BWM Convention were provided, and are now in the hands of the political will of the Adriatic countries to enable their use for the sake of protection of the Adriatic Sea environment, human health property and resources from negative impacts of ballast water being discharged in the area. Data, approaches and tools hereby provided may be helpful in any other region to support an effective BWM Convention implementation.

\section{Acknowledgements}

This work benefitted from the EU-funded project VECTORS, and for further development we received financial assistance of the IPA Adriatic Cross-Border Cooperation Programme - strategic project Ballast Water Management System for Adriatic Sea Protection (BALMAS). The contents of this publication are the sole responsibility of authors and can under no circumstances be regarded as reflecting the position of the IPA Adriatic Cross-Border Cooperation Programme Authorities.

\section{References}

Anadón, J.D., Giménez, A., Ballestar, R., Pérez, I., 2009. Evaluation of local ecological knowledge as a method for collecting extensive data on animal abundance. Conserv. Biol. 23, 617-625. https://doi.org/10.1111/j.1523-1739.2008.01145.x.

Artegiani, A., Bregant, D., Paschini, E., Pinardi, N., Raicich, F., Russo, A., 1997. The Adriatic Sea general circulation. Part II: Baroclinic Circulation Structure. Journal of Physical Oceanography 27, 1515-1532.

Awad, A., Haag, F., Anil, A.C., Abdulla, A., 2014. GEF-UNDP-IMO GloBallast Partnerships programme, IOI, CSIR-NIO and IUCN. Guidance on Port Biological Baseline Surveys. GEF-UNDP-IMO GloBallast Partnerships, London, UK. GloBallast Monograph No. 22. Azzurro, E., Moschella, P., Maynou, F., 2011. Tracking signals of change in Mediterranean 
fish diversity based on local ecological knowledge. PLoS One 6 (9), e24885. https:// doi.org/10.1371/journal.pone.0024885.

Azzurro, E., Bolognini, L., Dragičević, B., Drakulović, D., Dulčić, J., Fanelli, E., Grati, F., Kolitari, J., Lipej, L., Magaletti, E., Marković, O., Matić-Skoko, S., Mavrič, B., Milone, N., Joksimović, A., Tomanić, J., Scarpato, A., Tutman, P., Vrdoljak, D., Zappacosta, F., 2019. Detecting the Occurrence of Indigenous and Non-indigenous Megafauna through Fishermen Knowledge: A Complementary Tool to Coastal and Port Surveys. (This issue).

Bailey, S.A., Deneau, M.G., Jean, L., Wiley, C.J., Leung, B., MacIsaac, H.J., 2011. Evaluating efficacy of an environmental policy to prevent biological invasions. Environ. Sci. Technol. 45, 2554-2561.

Baldrighi, E., Semprucci, F., Franzo, A., Cvitkovic, I., Bogner, D., Despalatovic, M., Berto, D., Malgorzata Formalewicz, M., Scarpato, A., Frapiccini, E., Marini, M., Grego, M., 2019. Meiofaunal Communities in Four Adriatic Ports: Baseline Data for Risk Assessment in Ballast Water Management. (This issue).

Balsamo, M., Semprucci, F., Frontalini, F., Coccioni, R. 2012. Meiofauna as a tool for marine ecosystem biomonitoring. In: Cruzado, A. (Ed.), Marine Ecosystems. In Tech Publisher, pp. 77-104.

Bishop, M.J., Hutchings, P.A., 2011. How useful are port surveys focused on target pest identification for exotic species management? Mar. Pollut. Bull. 62, 36-42. https:// doi.org/10.1016/j.marpolbul.2010.09.014.

Cabrini, M., Cerino, F., de Olazabal, A., Di Poi, E., Fabbro, C., Fornasaro, D., Goruppi, A., Flander-Putrle, V., Francé, J., Gollasch, S., Hure, M., Lipej, L., Lučić, D., Magaletti, E., Mozetič, P., Tinta, T., Tornambè, A., Turk, V., Uhan, J., David, M., 2019. Potential Transfer of Aquatic Organisms Via Ballast Water With a Particular Focus on Harmful and Non-indigenous Species: A Survey From Adriatic Ports. (This issue).

Carlton, J.T., 1985. Transoceanic and interoceanic dispersal of coastal marine organisms: the biology of ballast water. Annu. Rev. Oceanogr. Mar. Biol. 23, 313-374.

Carlton, J.T., Reid, D., van Leeuwen, H. 1995. Shipping study, the role of shipping in the introduction of nonindigenous aquatic organisms to the coastal waters of the United States (other than the Great Lakes) and an analysis of control options. The National Sea Grant College Program/Connecticut Sea Grant Project R/ES-6, report no. CG-DII95. pp. 373.

Casas-Monroy, O., Roy, S., Rochon, A., 2011. Ballast sediment-mediated transport of nonindigenous species of dinoflagellates on the East Coast of Canada. Aquat. Invasions 6 (3), 231-248.

Chan, F.T., Stanislawczyk, K., Sneekes, A.C., Dvoretsky, A., Gollasch, S., Minchin, D., David, M., Jelmert, A., Albretsen, J., Bailey, S.A., 2019. Climate change opens new frontiers for marine species in the Arctic: current trends and future invasion risks. Glob. Chang. Biol. 25, 25-38. https://doi.org/10.1111/gcb.14469.

Cozzi, S., Giani, M., 2011. River water and nutrient discharges in the northern Adriatic Sea: current importance and long term changes. Cont. Shelf Res. 31, 1881-1893.

David, M. 2007. A Decision Support System Model for Ballast Water Management of Vessels. University of Ljubljana, Ljubljana, Doctoral dissertation $271 \mathrm{pp}$.

David, M., Gollasch, S., 2008. EU shipping in the dawn of managing the ballast water issue. Mar. Pollut. Bull. 56 (12), 1966-1972.

David, M., Gollasch, S. 2014. Review of ballast water discharge risk assessment tools, and new decision support systems for EU ports to avoid aquatic species invasions. In: final report. Prepared during project Vectors of change in oceans and seas marine life, impact on economic sectors (VECTORS), (285 pp).

David M. and Gollasch S. Risk Assessment for Ballast Water Management - Learning from the Adriatic Sea Case Study., (This issue)

David, M., Gollasch, S., Cabrini, M., Perkovič, M., Bošnjak, D., Virgilio, D., 2007. Results from the first ballast water sampling study in the Mediterranean Sea - the port of Koper study. Mar. Pollut. Bull. 54, 53-65.

David, M., Gollasch, S., Leppäkoski, E., 2013. Risk assessment for exemptions from ballast water management. Mar. Pollut. Bull. 75 (1), 205-217.

David, M., Gollasch, S., Elliott, B., Wiley, C., 2015a. Ballast water management under the ballast water management convention. In: David, M., Gollasch, S. (Eds.), Global Maritime Transport and Ballast Water Management - Issues and Solutions. Springer Science + Business Media, Dordrecht, Heidelberg, New York, London, pp. 89-108. https://doi.org/10.1007/978-94-017-9367-4.

David, M., Gollasch, S., Leppäkoski, E., Hewitt, C., 2015b. Risk assessment in ballast water management. In: David, M., Gollasch, S. (Eds.), Global Maritime Transport and Ballast Water Management - Issues and Solutions. Springer Science + Business Media, Dordrecht, Heidelberg, New York, London, pp. 133-170. https://doi.org/10.1007/ 978-94-017-9367-4. (p. 306).

David, M., Penko, L., Zupančič, G., Gosar, L., 2016. Ballast water discharge assessment methods and analysis of ballast discharge patterns in the Adriatic area. Final report, BALMAS project, p. 150

Di Poi, E., Kraus, R., Cabrini, M., Finotto, S., Flander-Putrle, V., Grego, M., Kužat, N., Ninčević Gladan, Ž., Pezzolesi, L., Riccardi, E., Bernardi Aubry, F., Bastianini, M., 2019. Dinoflagellate Resting Cysts from Surface Sediments of the Adriatic Ports: Distribution and Potential Spreading Patterns. (This issue).

Field, K.G., Samadpour, M., 2007. Fecal source tracking, the indicator paradigm, and managing water quality. Water Res. 41, 3517-3538.

Gollasch, S., 2006. Overview on introduced aquatic species in European navigational and adjacent waters. Helgol. Mar. Res. 60, 84-89.

Gollasch, S., David, M., 2018. How to approach ballast water management in European seas. Estuarine Coastal and Shelf Science 201, 248-255.

Gollasch, S., Macdonald, E., Belson, S., Botnen, H., Christensen, J., Hamer, J., Houvenaghel, G., Jelmert, A., Lucas, I., Masson, D., McCollin, T., Olenin, S., Persson, A., Wallentinus, I., Wetsteyn, B., Wittling, T. 2002. Life in ballast tanks. Invasive aquatic species of Europe: distribution, impacts and management (eds. Leppäkoski, E., S. Gollasch, and S. Olenin). Dordrecht: Kluwer Academic Publishers.

Gollasch, S., Minchin, D., David, M., 2015. The transfer of harmful aquatic organisms and pathogens with ballast water and their impacts. In: David, M., Gollasch, S. (Eds.), Global Maritime Transport and Ballast Water Management Issues and Solutions. Invading Nature. Springer Series in Invasion Ecology 8 Springer Science + Business Media, Dordrecht, Netherlands, pp. 35-47. https://doi.org/10.1007/978-94-0179367-4_3.

Gollasch, S., Hewitt, C.L., Bailey, S., David, M., 2019. Introductions and Transfers of Species by Ballast Water in the Adriatic Sea. (This issue).

Gooday, A.J., Levin, L.A., da Silva, A.A., Bett, B.J., Cowie, G.L., Dissard, D., Gage, J.D., Hughes, D.J., Jeffreys, R., Lamont, P.A., Larkin, K.E., 2009. Faunal responses to oxygen gradients on the Pakistan margin: a comparison of foraminiferans, macrofauna and megafauna. Deep-Sea Research Part II Topical Studies Oceanography 56, 488-502. https://doi.org/10.1016/j.dsr2.2008.10.003.

Grilli, F., Marini, M., Book, J.W., Campanelli, A., Paschini, E., Russo, A., 2013. Flux of nutrients between the middle and southern Adriatic Sea (Gargano-Split section). Mar. Chem. 153, 1-14.

Hewitt, C.L., Martin, R.B. 1996. Port surveys for introduced marine species - background considerations and sampling protocols. In: CRIMP Tech. Rep. No. 4. CSIRO Division of Fisheries, Hobart (40 pp).

Hewitt, C.L., Martin, R.B. 2001. Revised protocols for baseline port surveys for introduced marine species: survey design, sampling protocols and specimen handling. In: Centre for Research on introduced marine pests. In: CRIMP tech. Rep. No. 22. CSIRO marine research, Hobart (46 pp).

Hulme, P.E., 2006. Beyond control: wider implications for the management of biological invasions. J. Appl. Ecol. 43, 835-847. https://doi.org/10.1111/j.1365-2664.2006. 01227.x.

IMO, 1973. International Convention for the Prevention of Pollution from Ships (MARPOL). Final Act of the International Conference on Marine Pollution 1973, Resolution 18. IMO, London.

IMO, 2004. International Convention for the Control and Management of Ships' Ballast Water and Sediments, London 2004. International Maritime Organization, London (36 pp).

IMO, 2007. Guidelines for Risk Assessment under Regulation A-4 of the BWM Convention (G7). Marine Environment Protection Committee, Resolution MEPC. 162(56), 13 July 2007. International Maritime Organization, London (16 pp).

Katsanevakis, S., Gatto, F., Zenetos, A., Cardoso, A.C., 2013. How many marine aliens in Europe? Management of Biological Invasions 4 (1), 37-42. https://doi.org/10.3391/ mbi.2013.4.1.05.

Katsanevakis, S., Tempera, F., Teixeira, H., 2016. Mapping the impact of alien species on marine ecosystems: the Mediterranean Sea case study. Divers. Distrib. 22 (6), 694-707. https://doi.org/10.1111/ddi.12429.

Klaoudatos, D., Kapiris, K., 2014. Alien crabs in the Mediterranean Sea: Current status and perspectives. In: Ardovini, C. (Ed.), Crabs: Global Diversity. Nova Science Publishers, Inc., Behavior and Environmental Threats, pp. 101-159.

Komadina, P., Zec, D. 1996. The Adriatic Sea - A particularly sensitive area. Istituto per lo Studio dei Trasporti nell' Integrazioni Economica Europea, Trieste, Italija, Trasporti Europei, nr.3/1996, 42-46.

Kraus, R., Supić, N., Precali, R., 2016. Factors favouring large organic production in the northern Adriatic: towards the northern Adriatic empirical ecological model. Ocean Sci. 12, 19-37.

Kraus, R., Ninčević-Gladan, Ž., Auriemma, R., Bastianini, M., Bolognini, L., Cabrini, M., Cara, M., Čalić, M., Campanelli, A., Cvitković, I., Despalatović, M., Dragičević, B., Drakulović, D., Dulčić, J., Flander-Putrle, V., Grati, F., Grego, M., Grilli, F., Jaklin, A., Janeković, I., Kolitari, J., Lipej, L., Magaletti, E., Marini, M., Matić-Skoko, S., Mavrič, B., Mikus, J., Mozetič, P., Orlando-Bonaca, M., Petović, S., Precali, R., Supić, N., Trabucco, B., Travizi, A., Žuljević, A., 2019a. Strategy of Port Baseline Surveys (PBS) in the Adriatic Sea. (This issue).

Kraus, R., Grilli, F., Supić, N., Janeković, I., Brailo, M., Cara, M., Bratoš Cetinić, A., Campanelli, A., Cozzi, S., D'Adamo, R., Djakovac, T., Dutour-Sikirić, M., FlanderPutrle, V., Francé, J., Joksimović, D., Klun, K., Kolitari, J., Kralj, M., Kušpilić, G., Marini, M., Matić, F., Mikuš, J., Ninčević-Gladan, Ž., Pansera, M., Pećarević, M., Precali, R., Prusina, I., Relitti, F., Santucci, A., Specchiulli, A., Škalic, D., 2019b. Oceanographic Characteristics of the Adriatic Sea - Support to Secondary HAOP Spread through Natural Dispersal. (This issue).

Lipizer, M., Partescano, E., Rabitti, A., Giorgetti, A., Crise, A., 2014. Qualified temperature, salinity and dissolved oxygen climatologies in a changing Adriatic Sea. Ocean Sci. 10, 771-797.

Lodge, D.M., Williams, S., MacIsaac, H.J., Hayes, K.R., Leung, B., Reichard, S., Mack, R.N., Moyle, P.B., Smith, M., Andow, D.A., Carlton, J.T., McMichel, A., 2006. Biological invasions: recommendations for US policy and management. Ecol. Appl. 16, 2035-2054. https://doi.org/10.1890/1051-0761(2006)016[2035:BIRFUP]2.0. $\mathrm{CO} ; 2$.

Luna, G.M., Manini, E., Turk, V., Tinta, T., D'Errico, G., Baldrighi, E., Baljak, V., Buda, D., Cabrini, M., Campanelli, A., Cenov, A., Del Negro, P., Drakulović, D., Fabbro, C., Glad, M., Grilec, D., Grilli, F., Jokanović, S., Jozić, S., Kauzlarić, V., Kraus, R., Marini, M., Mikuš, J., Milandri, S., Pećarević, M., Perini, L., Quero, G.M., Šolić, M., Vukić Lušić, D., Zoffoli, S. , Status of faecal pollution in ports: A basin-wide investigation in the Adriatic Sea. (This issue).

Magaletti, E., Garaventa, F., David, M., Castriota, L., Kraus, R., Luna, G.M., Silvestri, C., Forte, C., Bastianini, M., Falautano, M., Maggio, T., Rak, G., Gollasch, S., 2018. Developing and testing an early warning system for non indigenous species and ballast water management. J. Sea Res. 133, 100-111.

Maglić, L., Zec, D., Frančić, V., 2016. Ballast water sediment elemental analysis. Mar. Pollut. Bull. 103 (1-2), 93-100.

Maglić, L., Frančić, V., Zec, D., David, M., 2019. Ballast Water Sediment Management in Ports. (This issue).

Marin, V., Moreno, M., Vassallo, P., Vezzulli, L., Fabiano, M., 2008. Development of a 
multistep indicator-based approach (MIBA) for the assessment of environmental quality of harbours. ICES J. Mar. Sci. 65, 1436-1441.

Marini, M., Russo, A., Paschini, E., Grilli, F., Campanelli, A., 2006. Short-term physical and chemical variations in the bottom water of middle Adriatic depressions. Clim. Res. 31, 227-237.

Marini, M., Jones, B. H., Campanelli, A., Grilli, F., Lee C. M. 2008. Seasonal variability and Po River plume influence on biochemical properties along western Adriatic coast. Journal of Geophysical Research 113, C05S90, doi:https://doi.org/10.1029/ 2007JC004370.

Marini, M., Maselli, V., Campanelli, A., Foglini, F., Grilli, F., 2016. Role of the midadriatic deep in dense water interception and modification. Mar. Geol. 375, 5-14.

Matsuoka, K., Fukuyo, Y., 2000. Technical guide for modern dinoflagellate cyst study, WESTPACHAB /WESTPAC/IOC, Japan Society of the Promotion Science. Tokyo. pp. 29.

Moreno, M., Vezzulli, L., Marin, V., Laconi, P., Albertelli, G., Fabiano, M., 2008a. The use of meiofauna diversity as an indicator of pollution in harbours. ICES J. Mar. Sci. 65, $1428-1435$.

Moreno, M., Ferrero, T.J., Gallizia, I., Vezzulli, L., Albertelli, G., Fabiano, M., 2008b. An assessment of the spatial heterogeneity of environmental disturbance within an enclosed harbour through the analysis of meiofauna and nematode assemblages. Estuar. Coast. Shelf Sci. 77, 565-576.

Moreno, M., Albertelli, G., Fabiano, M., 2009. Nematode response to metal, PAHs and organic enrichment in tourist marinas of the Mediterranean Sea. Mar. Pollut. Bull. 58, 1192-1201.

Mozetič, P., Cangini, M., Francé, J., Bastianini, M., Bernardi Aubry, F., Bužančić, M., Cabrini, M., Cerino, F., Čalić, M., D'Adamo, R., Drakulović, D., Finotto, S., Fornasaro, D., Grilli, F., Kraus, R., Kužat, N., Marić Pfannkuchen, D., Ninčević Gladan, Ž., Pompei, M., Rotter, A., Servadei, I., Skejić, S., 2019. Phytoplankton Diversity in Adriatic Ports: Lessons from the Port Baseline Survey for the Management of Harmful Algal Species. (This issue).

Olenin, S., Elliott, M., Bysveen, I., Culverhouse, P.F., Daunys, D., Dubelaar, G.B., Gollasch, S., Goulletquer, P., Jelmert, A., Kantor, Y., Mézeth, K.B., 2011. Recommendations on methods for the detection and control of biological pollution in marine coastal waters. Mar. Pollut. Bull. 62, 2598-2604. https://doi.org/10.1016/j.marpolbul.2011. 08.011 .

Olenin, S., Ojaveer, H., Minchin, D., Boelens, R., 2016. Assessing exemptions under the ballast water management convention: preclude the Trojan horse. Mar. Pollut. Bull. 103, 84-92. https://doi.org/10.1016/j.marpolbul.2015.12.043.

Perini, F., Bastianini, M., Capellacci, S., Pugliese, L., DiPoi, E., Cabrini, M., Buratti, S., Marini, M., Penna, A., 2019. Molecular Methods for Cost-Efficient Monitoring of HAB (Harmful Algal Bloom) Dinoflagellate Resting Cysts. (This issue).

Petrocelli, A., Antolić, B., Bolognini, L., Cecere, E., Cvitković, I., Despalatović, M., Falace, A., Finotto, S., Iveša, L.J., Mačić, V., Marini, M., Orlando-Bonaca, M., Rubino, F., Trabucco, B., Žuljević, A., 2019. Port Baseline Biological Surveys and Seaweed Bioinvasions in Port Areas: What's the Matter in the Adriatic Sea? This issue.

Pimentel, D., Zuniga, R., Morrison, D., 2005. Update on the environmental and economic costs associated with alien-invasive species in the United States. Ecol. Econ. 52, 273-288.

Rak, G., Zec, D., Markovčić Kostelac, M., Joksimović, D., Gollasch, S., David, M., 2019. The Implementation of the Ballast Water Management Convention in the Adriatic Sea through States' Cooperation: The Contribution of Environmental Law and Institutions. (This issue).

Reker, J., de Carvalho Belchior, C., Royo Gelabert, E., EEA Lead Authors, 2015. State of Europe's Seas. European Environment Agency (EEA) Report No 2/2015. https://doi. org/10.2800/64016. (216 pp).

Romanelli, G., Berto, D., Calace, N., Amici, M., Maltese, S., Formalewicz, M., Campanelli, A., Marini, M., Magaletti, E., Scarpato, A., 2019. Ballast Water Management System: Assessment of Chemical Quality Status of Several Ports in Adriatic Sea. (This issue).

Shine C, Kettunen M, Genovesi P, Essl F, Gollasch S, Rabitsch W, Scalera R, Starfinger U, ten Brink P (2010) Assessment to support continued development of the EU strategy to combat invasive alien species. Final report for the European Commission. Institute for European Environmental Policy (IEEP), Brussels.

Spagnolo, A., Auriemma, R., Bacci, T., Balković, I., Bertasi, F., Bolognini, L., Cabrini, M., Cilenti, L., Cuicchi, C., Cvitković, I., Despalatović, M., Grati, F., Grossi, L., Jaklin, A.,
Lipej, L., Marković, O., Mavrič, B., Mikac, B., Nasi, F., Nerlović, V., Pelosi, S., Penna, M., Petović, S., Punzo, E., Santucci, A., Scirocco, T., Strafella, P., Trabucco, B., Travizi, A., Žuljević, A., 2019. Non-indigenous Macrozoobenthic Species on Hard Substrata of Selected Harbours in the Adriatic Sea. (This issue).

Travizi, A., Balković, I., Bacci, T., Bertasi, F., Cuicchi, C., Flander-Putrle, V., Grati, F., Grossi, L., Jaklin, A., Lipej, L., Mavrič, B., Mikac, B., Marusso, V., Montagnini, L., Nerlović, V., Penna, M., Salvalaggio, V., Santelli, A., Scirocco, T., Trabucco, B., Spagnolo, A., 2019. Macrozoobenthos in the Adriatic Sea Ports: Soft-Bottom Communities with an Overview of Non-indigenous Species. (This issue).

van den Bergh, J.C.J.M., Nunes, P.A.L.D., Dotinga, H.M., Kooistra, W.H.C.F., Vrieling, E.G., Peperzak, L., 2002. Exotic harmful algae in marine ecosystems: an integrated biological-economic-legal analysis of impacts and policies. Mar. Policy 26, 59-74.

Vidjak, O., Bojanić, N., de Olazabal, A., Benzi, M., Brautović, I., Camatti, E., Hure, M. Lipej, L., Lučić, D., Pansera, M., Pećarević, M., Pestorić, B., Pigozzi, S., Tirelli, V. Zooplankton in Adriatic port environments: Indigenous communities and non-indigenous species. (This issue).

Vila, M., Basnou, C., Pyšek, P., Josefsson, M., Genovesi, P., Gollasch, S., Nentwig, W., Olenin, S., Roques, A., Roy, D., Hulme, P.E., DAISIE Partners, 2010. How well do we understand the impacts of alien species on ecosystem services? A pan-European crosstaxa assessment. Frontiers of Ecology and Environment 8, 135-144.

Williams, R.J., Griffiths, F.B., Van der Wal, E.J., Kelly, J., 1988. Cargo vessel ballast water as a vector for the transport of non-indigenous marine species. Estuar. Coast. Shelf Sci. 26, 409-420.

Zavatarelli, M., Raicich, F., Bregant, D., Russo, A., Artegiani, A., 1998. Climatological biogeochemical characteristics of the Adriatic Sea. J. Mar. Syst. 18, 227-263.

Zec, D., Frančić, V., Maglić, L., Šimić Hlača, M., Vukelić, M., Radić, I., Markovčić Kostelac, M., Vidas, S. 2015. Written contribution to the Act. 4.1. BALMAS project. Work package 4. Action 4.1, (55 pp).

Zenetos, A., Gofas, S., Morri, C., Rosso, A., Violanti, D., García Raso, J.E., Çinar, M.E., Almogi-Labin, A., Ates, A.S., Azzurro, E., Ballesteros, E., Bianchi, C.N., Bilecenoglu, M., Gambi, M.C., Giangrande, A., Gravili, C., Hyams-Kaphzan, O., Karachle, P.K., Katsanevakis, S., Lipej, L., Mastrototaro, F., Mineur, F., Pancucci-Papadopoulou, M.A., Ramos Esplá, A., Salas, C., San Martín, G., Sfriso, A., Streftaris, N., Verlaque, M., 2012. Alien species in the Mediterranean Sea by 2012. A contribution to the application of European Union's marine strategy framework directive (MSFD). Part 2. Introduction trends and pathways. Mediterr. Mar. Sci. 13 (2), 328-352.

Zeppilli, D., Sarrazin, J., Leduc, D., Arbizu, P.M., Fontaneto, D., Fontanier, C., Gooday, A.J., Kristensen, R.M., Ivanenko, V.N., Sorensen, M.V., Vanreusel, A., Thébault, J., Mea, M., Allio, N., Andro, T., Arvigo, A., Castrec, J., Danielo, M., Foulon, V., Fumeron, R., Hermabessiere, L., Hulot, V., James, T., Langonne-Augen, R., Le Bot, T., Long, M., Mahabror, D., Morel, Q., Pantalos, M., Pouplard, E., Raimondeau, L., RioCabello, A., Seite, S., Traisnel, G., Urvoy, K., Van Der Stegen, T., Weyand, M., Fernandes, D., 2015. Is the meiofauna a good indicator for climate change and anthropogenic impacts? Mar. Biodivers. 45, 505-535.

Zupančič, G., Gosar, L., David, M. 2015. Report summarizing and analysing shipping patterns in the Adriatic Sea - upgrade (Final beta report). BALMAS project. Work package 4. Action 4.1, $37 \mathrm{pp}$.

Matej David ${ }^{\mathrm{a}, *}$, Erika Magaletti ${ }^{\mathrm{b}}$, Romina Kraus ${ }^{\mathrm{c}}$, Mauro Marini ${ }^{\mathrm{d}}$ ${ }^{a}$ Dr. Matej David Consult, Korte 13e, 6310 Izola, Slovenia

${ }^{\mathrm{b}}$ ISPRA - National Institute for Environmental Protection and Research, via Vitaliano Brancati 48, 00166 Rome, Italy

${ }^{\mathrm{c}}$ Ruđer Bošković Institute, Center for Marine Research, Giordano Paliaga 5, 52210 Rovinj, Croatia

${ }^{\mathrm{d}}$ National Research Council, CNR-IRBIM, Largo Fiera della Pesca 2, 60125 Ancona, Italy

E-mail addresses: matej.david@siol.net (M. David), erika.magaletti@isprambiente.it (E. Magaletti),

kraus@cim.irb.hr (R. Kraus), mauro.marini@cnr.it (M. Marini).

${ }^{*}$ Corresponding author. 